DOI: $10.31558 / 2308-1902.2018 .26 .6$

УДК 821.161.2: Бендер

Антон БУЗОВ

асистент, Донецький національний університет імені

Василя Стуса

\title{
ВИГНАННЯ ЯК ТЕКСТ У МАЛІЙ ПРОЗІ ВІТАЛІЯ БЕНДЕРА
}

У статті розглянуто ідейно-філософську візію еміграційного буття, відображену в малій прозі Віталія Бендера - українського письменника, журналіста, громадського діяча еміграції другої половини XX століття. Простежено паралелі між реалізованою Бендером поетикою вигнання та апеляціями прозаїка до екзистенційної проблематики в новелістиці повоєнної доби. Віталій Бендер розглядає життя емігранта як неперервну екзистенційну ініціацію в новому просторі, відтак можна стверджувати про органічну світоглядну приналежність автора та його творчості до загального мистецько-філософського дискурсу української письменницької діаспори повоєнної доби.

Ключові слова: екзистенціалізм, поетика, мотив, буття, ініціація, вигнання, відчуження, еміграція.

Нам з тобою бігти вздовж соняшникових полів. Нам з тобою тікати від псів, спати поміж волів. Нам збирати воду в долоні, чекаючи в таборах, дратувати драконів на бойових прапорах

(Сергій Жадан)

Звернення до мистецької спадщини Віталія Бендера сьогодні $\epsilon$ своєрідним жестом повернення цього незаслужено невідомого на Батьківщині імені до літературного й навкололітературного обігу. Практика, коли за кордоном митець дістає більше визнання, ніж у рідній країні, загалом характерна для українського літературного процесу XX століття, протягом якого був витворений цілий масив художніх текстів письменників-емігрантів, більшість із яких мала лише етнічний зв'язок із Україною, із різним успіхом адаптувавшись на зарубіжних теренах. Доробок Віталія Бендера - прозаїка i публіциста, практично все творче життя якого пройшло у Великій Британії, досі $\epsilon$ непоцінованим на його Батьківщині. Це підтверджує вкрай незначна кількість розвідок, присвячених літературній і публіцистичній спадщині митця.

Так, у словнику-довіднику «Українська діаспора: літературні постаті, твори, біобібліографічні відомості» за редакцією Віри Просалової [12], що є 
одним із найповніших довідкових видань подібного характеру в сучасній україністиці, подано переважно джерела мемуарного характеру, що стосуються біографії письменника. Лаконічні спогади про Віталія Бендера залишили Р. Василенко [5], М. Дальний [7], І. Качуровський [8]. Найповніше на сьогодні видання творів письменника [1] містить передмову О. Коновала, у якій подано короткі відомості про життєвий шлях літератора, проте повністю відсутні спроби фахового аналізу текстів Бендера [10].

Перераховані розвідки відзначені бодай побіжним інтересом до постаті письменника, чого не можна сказати про решту спеціалізованих видань, присвячених літературному процесу в еміграції. Так, наприклад, у монографії В. Мацька «Українська еміграційна проза XX століття» [11] життєвий i творчий шлях Віталія Бендера повністю проігноровано, незважаючи на декларовану в назві праці вичерпність наукової візії діаспорної прози.

Літературно-публіцистичний доробок митця становить об'єкт аналізу кількох розвідок вітчизняних літературознавців. Стаття Віри Просалової присвячена реалізації проблеми «автор-герой» у романі «Фронтові дороги» [13]. Дослідження проблемного поля есеїстики В. Бендера було здійснене Валентиною Галич [6]. У розвідках автора цієї статті здійснено аналіз ідейноестетичних домінант роману «Фронтові дороги» [3], розглянуто поетикальні ознаки малої прози Віталія Бендера [4].

Український мистецький екзил витворив потужний пласт оригінальних літературних текстів, багато 3 яких досі очікують на свого дослідника. Прочитання української еміграційної прози є актуальним, адже комплекс мотивів творчості письменників-діаспорян перебуває в тісному зв'язку 3 конкретними фактами їх життєпису, насиченого революціями, війнами, вимушеним вигнанням. Не є винятком у цьому аспекті й Віталій Бендер, який був активним учасником Другої світової війни - спочатку в складі радянської армії, а потім і в лавах Першої дивізії УНА. Тому перспективним виглядає прочитання малої прози автора в дискурсі еміграційного письма 3 метою визначення механізмів впливу обставин написання на поетику твору. 
Мета статті - визначення специфіки еміграційного світосприйняття як важливої ознаки авторської стратегії у новелістиці Віталія Бендера. Завдання статті - простежити шляхи реалізації ключових ознак поетики вигнання в зазначеному творі. Об'єктом дослідження обрано малу прозу Віталія Бендера.

Події, що ставлять цілий народ на межу виживання, як не парадоксально, сприяють виявленню найкращих рис його характеру, що, власне, і допомагають нації вижити в ситуації вирішальних випробувань. Хвиля еміграції, до якої належав Віталій Бендер, була інспірована подіями Другої Світової війни. Війна та еміграція - дві магістральні проблеми, до яких письменник звертався у своїй малій прозі. Це ті ситуації, в яких особливо гостро відчувається ціна людського існування - те, на що не звертається уваги у мирні часи. Російський філософ Микола Бердяєв писав про природу загостреного, екзистенційного світоусвідомлення, шлях до якого відкривають граничні стани - війна, необхідність залишати Батьківщину та починати життя наново в несприятливих умовах: «В Євангелії сказано, що треба більше боятися тих, хто вбиває душу, ніж тих, хто убиває тіло. Фізична смерть менш страшна, ніж смерть духовна. А до війни, в мирному житті, вбивалися людські душі, притлумлювався людський дух, і це стало настільки звичним, що всі перестали навіть помічати жах цього вбивства. На війні руйнують фізичну оболонку людини, ядро ж людини, іiі душа може залишитися не тільки не зруйнованою, але й має шанс навіть відродитися» [2, с. 247].

Еміграція є питомим супутником свідомого українського воїнства у XX столітті. Вона ж постає чи не найдраматичнішим досвідом ініціації спроби включитися до життя в новому просторі, що у кращому випадку є нейтрально-байдужим до новоприбулого, а в гіршому - виявляє свою відверту ворожість до нього. В таких умовах як сам Бендер, так і його герої, в яких достатньо помітною $є$ автобіографічна основа, змушені витворювати нову ідентичність, намагаючись якомога менше втратити вже наявну самість. 
Єдиною зброєю, доступною цим людям, $є$ своєрідний стоїцизм як форма боротьби за людську гідність.

Мала проза Віталія Бендера, написана в період повоєнної еміграції, загалом суголосна окресленому комплексу екзистенційної проблематики. Її масив являє собою контроверсійне полотно людського буття, неповторність якого виявляється у найбільш типових життєвих ситуаціях.

Новела «Клопа-клопо» змальовує зустріч двох українських емігрантів у Лондоні. Симптоматичним здається навіть день, коли вона відбувається четвер, «тяжкий день, найсумніший та найсіріший» [1, с. 752], оскільки це останній день перед виплатою заробітної платні в Англії. Відповідно, оповідач спочатку не планує нікуди виходити, аби заощадити залишки грошей. Однак суголосна його млявому настрою сумна мелодія, що лунає 3 найближчої кнайпи, змушує його долучитися до товариства молодика, який має «апатичне обличчя стомленої людини» [1, с. 752]. Слід зазначити, що оповідач також виявляє риси певної втомленості від життя та спілкування 3 людьми, так, зокрема, він дуже щасливий з прямоти свого співрозмовника, оскільки досвід розмов із людьми, що розпочинають розмову «втертим “Як живете?” - “Та... нічого”» [1, с. 753], не викликає в нього особливого захоплення.

Молодий чоловік не один, він має постійну супутницю, вродливу, проте особливої уваги ій не приділяє. Він весь поринає у сумну мелодію невідомого оповідачеві мотиву, назва якого є назвою самої новели - «Клопаклопо». Співрозмовник оповідача відразу попереджає, що мажорні акорди самби, румби чи квік-степу йому чужі, адже він перебуває у постійному стані «клопа-клопо», тобто «безцільно блукає вулицями, сумуючи й нудьгуючи» [1, с. 752]. Молодик свідомий своєї алієнованості щодо британського ландшафту, він відчуває власну відчуженість не лише від англійської дійсності, а й загалом - від певного стандартного набору людських цінностей, які ніколи не замінять йому втраченої Батьківщини. Цим-таки пояснюється і доволі холодне ставлення юнака до своєї чарівної супутниці. 
Вони є вихідцями з різних світів, які не мають шансу асимілюватися один до одного, як і молодий українець - до західної дійсності: «Вона... - гарна дівчина, але я ніколи не одружуся з нею... Просто не хочу розвіювати їі мрії про родинне життя, бо доки мої думки літатимуть над рідною Одесою..., вона завжди буде на другому місці» [1, с. 754]. Герой Бендера усвідомлює своє «незнаходження» в локації свого фізичного перебування, він там, де його думки, що поглиблюють конфлікт між ідеальним існуванням та ворожою дійсністю, компонентами якої є і четвергова порожня кнайпа на лондонській околиці, та навіть усміхнена дівчина поруч із ним.

Попри екзистенційну тугу, героєві притаманний трагічний оптимізм, намагання побороти долю. Так, молодик зізнається: «Хотів записатися до англійської комерційної фльоти, думав вирватися з цієї тісноти на океанські простори - не прийняли. Тепер думаю про французький чужинецький легіон» [1, с. 754]. Звідси - і своєрідне життєве кредо героя новели: «Я тужу, бо маю серце, і надіюся, бо вірю в прийдешній день» [1, с. 754]. Бендерів герой заперечує класичне contra spem spero, бо існування надії для нього настільки ж безперечне, як і його одвічна туга, що стала способом життя. Отже, маємо трагічний стоїцизм як світоглядний вибір «трохи стомленого, але не зломаного молодого українця» $[1$, с. 755$]$.

В етюді «Осінь» автор відтворює світобачення тридцятирічної людини, яка вже встигла багато побачити й тепер споглядає зміну пір року, мимохіть відволікаючись від читання. Книга не приносить оповідачу особливого задоволення, він механічно гортає сторінки, бо не може подолати впливу вміщеної у ній розповіді про весну. Йому запропоновано втечу від реальності у вигадані ідеальні світи прийдешньої весни, однак оповідач чинить спротив цій спробі та переключає свою увагу на осінні картини, одна з яких живе за вікном, а інша - в його пам'яті як полотно, колись побачене на виставці. Живописна екфраза, що виринає в уяві героя етюду, являє йому більш бажане видиво - золоту, красиву осінь, що розливає в повітрі багрянець пожовклого листя та особливу, п'янку свіжість. Натомість, те, що 
відбувається за вікном, разюче відрізняється від уявного: «В повітрі, на вулиці, в кімнаті - пригноблюючий песимізм» [1, с. 756].

Проте оповідач не впадає у розпач, а зголошується на справжній бунт. А що, коли осінь, яка була на згаданому ним полотні, насправді була не такою яскравою, розкішною, чарівною, привітною, а навпаки, всі осені художника були «заплаканими, захлисканими печаллю, отакими понурими, як і оця, що тепер ридає за вікном?» [1, с. 756]. I протагоніст вирішує не піддаватися гнітючій реальності, усвідомити, що осінь - не така, якою він іiі бачить, а така, якою вона має бути для нього. «Осінь нашого життя МУСИТЬ (виділення Віталія Бендера. - А. Б.) бути золотою» [1, с. 756]. Він готовий прийняти всі негаразди буття (бо розуміємо, що осінь - це лише влучна метафора, в якій криється дещо більше), аби лише вчинити йому спротив, що, можливо, є цілковито безглуздим, адже осінь не перестане бути осінню із дощами, холодними вітрами та погіршенням погодних умов. Проте в екзистенційному вимірі такий протест є своєрідним протестом честі, коли людина опирається небажаним явищам чи процесам дійсності без особливого шансу на успіх, але 3 розумінням того, що в іншому разі вона не зможе усвідомлювати себе людиною.

Новела «Людина з Чорного моря» є біографічним спогадом про зміни в житті людини, що втратила все і не може пристосуватися до змінених умов існування. Таким відчуженим від колишнього щастя персонажем постає дядько оповідача, моряк чорноморського флоту. Матрос, який приїздить у відпустку до рідного шахтарського містечка, одразу стає кумиром місцевої дітлашні, а невід’ємні атрибути «морського вовка» - безкозирка з назвою корабля, на якому він ходить у море, специфічний моряцький жаргон - витворюють навколо чоловіка атмосферу своєрідної таємничості. Однак усе змінюється, коли міноносець «Різвий» переплавляють на бронепоїзд, а колишнього матроса ставлять ним командувати. В нього немає жодних радощів від такого підвищення, навпаки, він утратив частину себе і не до кінця розуміє, як почуватися і поводитися в нових, змінених умовах: «Спочиває «Різвий» на дні... 
Маєш тепер «Южный фронт» і «Дядю Ваню», а Чорне море... - що він хотів сказати, не знаю, але його тяжке зітхання вирвалося, як біль зраненої людини» $[1$, c. 759]. Моряк переживає втрату бойового корабля і втрату моря як загибель справжнього товариша, і його світ уже ніколи не стане колишнім: «Не можу без моря і скиглення чайок» $[1$, с. 759$]$.

Доля дарує оповідачеві зустріч із старим моряком лише в чужому краї, що дуже далекий від рідного Чорного моря: «Ми зустрілися на березі ЛяМаншу... Часто він виходив на берег, сідав на камінь і, посвистуючи «Ми 3 Одеси моряки», годинами вдивлявся в сині хвилі протоки...» [1, с.760]. Матрос намагається деконструювати колишню дійсність, зокрема, останнім зв'язком із морем для нього стає чорна стрічка з безкозирки з написом «М-ць «Різвий». Проте невміння та небажання прилаштовуватися до нового життя, ба навіть відмова сприймати суходол як такий («В бараці, який він називав “кубриком”» $[1$, с. 760]), призводять до остаточної втрати сенсу життя та поступового згасання старого: «Хвороба, яку він називав нудьгою, цупко вп'ялася в його душу, і лише міноносець «Різвий» міг би тепер його вилікувати» [1, с. 760]. Спостерігаємо у цьому випадку змалювання екзистенційної нудьги численних українських емігрантів, які вкрай важко переносили розлуку з рідним краєм, усталеним побутом, так і не змігши пристосуватися до нової дійсності.

Аналогічне небажання розлучатися із минулим, що поєднане, втім, із розумінням необхідності такого кроку, наявне в новелі «Прощай, паротяг!..» Маємо тут той випадок, коли розум усвідомлює, а серце - не хоче. Головному героєві, статечній людині, яка має сина i перелік посад у діаспорній номенклатурі, йдеться не просто про паротяг, а про символ найкращих, «жарких» літ юності, проведених у гармонії із самим собою, задовго до еміграції та соціальних потрясінь середини XX століття. Відхід паротяга ототожнюється 3 відходом щасливого, назавжди втраченого життя на Батьківщині: «I враз якось не стало жарких літ. Життя набирало шаленого темпу, літа почали видаватися коротшими й холоднішими... I скільки доріг 
пройдено, і скільки шляхів з’іжджено!» [1, с. 765]. Оповідач усвідомлює, що минула ера не лише паротяга - його власне життя наближається до кінця, його час минає: «Ні, ера таки скінчилася. Тому, хто не був іiі свідком, цілком байдуже. Мені ж - дуже боляче» [1, с. 766]. Герою боляче навіть не тільки й не стільки від того, що відходить епоха - йдеться про те, що поруч немає людини, яка зрозуміє всю значущість втрати та зможе розділити іï з ним. Оповідач та його син представляють різні буттєві історії, одна з яких закінчується, а друга майже ніяк не перетинається 3 нею. «Чим і як цей біль можна висловити? Та чи й потрібно?» [1, с. 752] - такими словами звертається сам до себе герой новели, усвідомлюючи, що нікому немає справи до його ностальгійних переживань та існування загалом, адже всеохопна байдужість ставить під сумнів саму легітимність таких рефлексій.

Новела «Моя вартість» багато в чому перегукується із експресіоністичними новелами Ігоря Костецького, якщо винести за дужки відчутну абсурдистську складову творчості останнього. Найпрозоріша паралель у цьому сенсі - «Моя вартість» Бендера та «Ціна людської назви» Костецького. Пригадуємо, що в Костецького за право на власне ім’я сперечаються два художники - молодий та старий. Відповідно розуміємо, що ім'я людини фактично тотожне іiі існуванню, чи ба навіть іiі вартості, адже людина знана цілком може мати зиск зі свого імені, з чого ніяк не може скористатися людина невідома. У випадку із «Моєю вартістю» йдеться про байдужість, зведену в квадрат - людину, яка потрапила за грати за якийсь дрібний бешкет, вперто ігнорують усі, до кого вона звертається. Лише головний герой знаходить час та гроші, аби визволити Ігоря із в'язниці, коли він уже втрачає надію і віру в людство. Конкретність ціни людської свободи тридцять п’ять фунтів - своєрідно окреслює їі межі для кожного. Ціна свободи корелює 3 ціною життя, отже, йдеться про екзистенційну проблематику у творі. Визволений із в’язниці Ігор розповідає своєму рятівникові: «Кого не просив у поручителі, всі відмовилися - священик, одноквартирники, знайомі. Невже, думаю, я отаке бидло, що вже нікому й непотрібний?». Акцентування 
на самотності героя, алієнації (відчуження) його від суспільства і суспільства від нього характерне для екзистенційного світобачення.

У новелі «Таємниця» змальований цілий спектр екзистенційних питань, відповідь на які шукають головні герої - дизайнер-початківець Грицько та «бальзаківська дама» Зоя. Їх багато що поєднує - взаємна самотність у чужій країні внаслідок змушеної еміграції, нереалізованість у житті: Грицько невдаха-учень у вечірній школі декораторів, пані Зоя, проживши сповнене труднощів життя, поступово перетворюється на молоду бабусю, від якої потрібний лише догляд за онуками: «Вони ж здавна звикли, що мамі вже нічого не треба, що я хороша і щедра бабуня, невимоглива й пасивна істота, яка вже звиклася $з$ подихами старості» [1, с. 826].

I на цьому тлі вибухає справжній екзистенційний бунт - без особливих шансів на успіх, протест заради самого протесту, що робить головних героїв щасливими. Роман молодика зі зрілою жінкою виглядає викликом суспільній моралі, проте це не має жодного сенсу для самих його учасників. Об’єднані спільною таємницею, коханці дають чітку відсіч упередженням щодо віку, врешті-решт ставши господарями власного буття, що дає можливість зруйнувати «замкнене коло» життєвих невдач, помилок: «І щойно тепер я до кінця усвідомлюю, яку ж болючу кривду ми чинили своїм матерям..., коли в сорок років... вважали їх старезними, вицвілими, захололими» [1, с. 835]. Характерно, що допоки закохані вірні своїй таємниці, їхнє життя стрімко налагоджується. Так, Григорій стає успішним i модним спеціалістом із облаштування інтер’єрів, Зоя натомість переживає другу молодість із коханим Грицем, усвідомлюючи, проте, що їхнє щастя дуже хитке, а перша-ліпша молода дівчина біля Грицька зруйнує таємницю їх кохання. Жінка розуміє необхідність рано чи пізно робити новий вибір і цілком свідома того, що довго подібне «подвійне життя» тривати не може: «Наше розкішне безумство підкочується до кінця, після чого нам залишиться лише далекий, голубий i милий спомин» [1, с. 836]. Зрештою, щастя закоханої пари завершується разом із втратою таємниці - Гриць помирає, Зоя залишається самотньою. 
Проте жалю від отриманого досвіду екзистенційного спротиву зовсім немає: «Який старий світ, а скільки в ньому ще білих плям!..» [1, с. 836]. Пережитий бунт існування проти дійсності дозволяє Грицьку та Зої значно глибше пізнати світ і знайти в ньому нові життєві сенси.

Отже, свідомо чи несвідомо обраний письменником вимір екзистенціалізму постає наслідком естетичних і філософських пошуків XX століття, що були сприйняті Бендером та художньо трансформовані в новелістиці повоєнних років. Екзистенційні проблеми, що їх доводиться розв'язувати його героям, $є$ відображенням тих глобальних та індивідуальних трагедій та катастроф, що справили величезний вплив на розвиток людської думки та самоусвідомлення й переживання свого буття у світі.

\section{ЛІТЕРАТУРА}

1. Бендер В. Марш молодости. Київ : Юніверс, 2005. 888 с.

2. Бердяев Н. А. Судьба России. Москва : АСТ, 2005. 333 с.

3. Бузов A. C. Дискурс експресіонізму в романі Віталія Бендера «Фронтові дороги». Актуальні проблеми української літератури $і$ фольклору. Випуск 23. Вінниця : ДонНУ, 2015. С. 70-79.

4. Бузов А. С. Стильові пошуки у малій прозі Віталія Бендера. Jahrbuch der VI Internationalen virtuellen Konferenz der Ukrainistik «Dialog der Sprachen - Dialog der Kulturen. Die Ukraine aus globaler Sicht» Reihe: Internationale virtuelle Konferenz der Ukrainistik. Діалог мов - діалог культур. Україна і світ. Мюнхен : KUBON \& SAGNER, 2016. С. 255-260.

5. Василенко Р. М. Ех, дороги // Життя в гримі та без (шляхами діаспори): мемуари, поезія, публіцистика. Київ : Рада, 1999. С. 366-369.

6. Галич B. М. Публіцистика Віталія Бендера: жанрово-стильові домінанти // Соціальні комунікації: теорія, історія, регіональний дискурс. Рівне : О. Зень, 2015. С. 23-46.

7. Дальний М. Вибране: Люди-події-коментарі. Київ: Видавничий дім «КиєвоМогилянська академія», 2007. 563 с.

8. Качуровський I. В. Покоління Другої світової війни в літературі української діаспори // Променисті сильвети. Київ : Києво-Могилянська академія, 2008. С. 514-531.

9. Коновал О. Г. Віталій Бендер про «Вогненне коло» Івана Багряного // Літературна Україна. 2011. 10 листопада. С. 11. C. 5-9.

10. Коновал О. Г. Жив з Україною в серці // Марш молодости. Київ : Юніверс, 2005.

11. Мацько В. П. Українська еміграційна проза XX століття. Хмельницький : ПП І. Ж. Дерепа, 2009. 388 с.

12. Просалова В. А. Віталій Бендер // Українська діаспора: літературні постаті, твори, біобібліографічні відомості. Донецьк : Східний видавничий дім, 2012. С. 27.

13. Просалова В.А. Проблема автор - герой у романі Віталія Бендера «Фронтові дороги». Вісник Донецького університету. Серія Б. Гуманітарні науки. 2015. № 1-2. C. 208-213. 


\section{REFERENCES}

1. Bender, V. Marsh molodosty [The March of Youth], Kyiv, Yunivers, 2005, 888 p [In Ukrainian].

2. Berdjaev, N. A. Sud'ba Rossii [The Fate of Russia], Moskva: AST, 2005. 333 p [In Russian].

3. Buzov, A. Dyskurs ekspresionizmu v romani Vitaliya Bendera "Frontovi dorogy» [Expressionistic discourse of the novel "Front-line roads" by Vitaly Bender], Aktual'ni problemy ukrayins'koyi literatury i fol'kloru: nauk. zb. [Actual problems of literature and folklore: collection of scientific works], No. 23, Vinny`cya, DonNU, 2015, pp. 70-79 [In Ukrainian].

4. Buzov, A. S. Styl'ovi poshuky u maliy prozi Vitaliya Bendera [Searching of style in the small prose by Vitaly Bender], Jahrbuch der VI Internationalen virtuellen Konferenz der Ukrainistik «Dialog der Sprachen - Dialog der Kulturen. Die Ukraine aus globaler Sicht» Reihe: Internationale virtuelle Konferenz der Ukrainistik. Dialog mov - dialog kul'tur. Ukrayina i svit [Dialogue of languages - dialogue of cultures. Ukraine and world], Munchen, KUBON \& SAGNER, 2016, pp. 255-260 [In Ukrainian].

5. Vasy'lenko, R. M. Ekh, dorogy [Oh, this roads], Zhyttya v grymi ta bez (shlyakhamy diaspory): memuary, poeziya, publitsystyka [The life in make-up and without (on the emigrate roads): memoires, poetry, publicism], Kyiv, Rada, 1999, pp. 366-369 [In Ukrainian].

6. Galy'ch, V. M. Publitsystyka Vitaliya Bendera: zhanrovo-styl'ovi dominanty [Publicism of Vitaly Bender: genre-style dominants], Social 'ni komunikaciyi: teoriya, istoriya, regional`ny`j dy`skurs: naukovy`j zbirny`k [Social communications: theory, history, regional discourse: collection of scientific works], Rivne, O. Zen`, 2015, pp. 23-46 [In Ukrainian].

7. Dal'ny'j, M. Vybrane: Lyudy-podiyi-komentari [Selected works: people-developmentscomments], Kyiv, Vydavnychyy dim «Kyyevo-Mohylyans'ka akademiya», 2007, 563 p [In Ukrainian].

8. Kachurovs'ky'j, I. V. Pokolinnya Drugoyi svitovoyi viyny v literaturi ukrayins'koyi diaspory [Generation of WWII in the literature of ukrainian emigration], Promenysti syl'vety [Radiant silhouettes], Kyiv, Ky`yevo-Mogy`lyans`ka akademiya, 2008, pp. 514-531 [In Ukrainian].

9. Konoval, O. G. Vitalij Bender pro «Voghnenne kolo» Ivana Baghrjanogho [Vitaly Bender about «The circle of fire» by Ivan Bagriany], Literaturna Ukrajina [Literary Ukraine], 2011, 10 lystopada, pp. 11-12 [In Ukrainian].

10. Konoval, O. G. Zhyv z Ukrayinoyu v sertsi [He lived with Ukraine in his heart], Marsh molodosty [The March of Youth], Kyiv, Yunivers, 2005, pp. 5-9 [In Ukrainian].

11. Mats'ko, V. P. Ukrayins'ka emigraciyna proza XX stolittya : monografiya [The prose of ukrainian emigration: the monograph], Khmelnytskyy, PP I.Zh.Derepa, 2009, 388 p [In Ukrainian].

12. Prosalova, V. A. Vitaliy Bender [Vitaly Bender], Ukrayins 'ka diaspora: literaturni postati, tvory', biobibliografichni vidomosti.[Ukrainian diaspore: literary figures, works, biobibliographical information], Donets'k: Skhidnyy vydavnychyy dim, 2012, p. 27 [In Ukrainian].

13. Prosalova, V. A. Problema avtor - geroy u romani Vitaliya Bendera "Frontovi dorogy" [The problem ,author - hero" in the novel "Front-line roads" by Vitaly Bender] Visnyk Donet'skogo universytetu. Seriya B. Gumanitarni nauky [The messenger of Donetsk National University. Series B. Human Sciences], 2015, No. 1-2, pp. 208-213 [In Ukrainian].

\section{АННОТАЦИЯ}

\section{Антон Бузов. Изгнание как текст в малой прозе Виталия Бендера}

В статье представлено идейно-философское видение эмиграционного бытия, отраженного в малой прозе Виталия Бендера - украинского писателя, журналиста, общественного деятеля эмиграции второй половины XX века. Прослежены параллели между реализованной Бендером поэтикой изгнания и апелляциями прозаика к экзистенциальной проблематике в 
новеллистике послевоенного времени. Виталий Бендер рассматривает жизнь эмигранта как непрерывную экзистенциальную инициацию в новом пространстве, однако можно утверждать органичную мировоззренческую принадлежность автора и его творчества к общему художественно-философскому дискурсу украинской писательской диаспоры послевоенного времени.

Ключевые слова: экзистенциализм, поэтика, мотив, бытие, инициация, изгнание, отчуждение, эмиграция

\section{ABSTRACT \\ Anton Buzov. The exile as a text in a small prose of Vitaly Bender}

The article deals with the ideological and philosophical vision of emigration being, reflected in the small prose of Vitaly Bender, a Ukrainian writer, journalist, social activist of emigration in the second half of the twentieth century.

It is noted that the appeal to the artistic heritage of Vitaliy Bender today is a kind of gesture of the return of this undeservedly unknown in the Homeland's name to the literary and polytheistic circulation. The practice when the artist gets more recognition abroad than in his native country is generally characteristic of the Ukrainian literary process of the twentieth century, during which a whole array of artistic texts of emigrant writers was created, most of which had only an ethnic connection with Ukraine, with different successfully adapting to foreign territories. The work of Vitaly Bender, a prose writer and essayist, practically all of whose creative life she has been in the UK, is still priceless in his homeland. This is confirmed by a very small number of explorations devoted to the literary and journalistic heritage of the artist.

It is emphasized that in the analyzed works of Vitaliy Bender the writer shows events that put the whole nation on the verge of survival, but paradoxically, they help to identify the best features of its character, which, in fact, help the nation to survive in a decisive situation. The wave of emigration, to which Vitaliy Bender belonged, was inspired by the events of the Second World War. War and emigration are two main problems to which the writer addressed his small prose. These are the situations in which the price of human existence is especially acute something that does not pay attention to peaceful times.

It is determined that the measure of existentialism, deliberately or unconsciously chosen by the writer, appears as a result of the aesthetic and philosophical searches of the twentieth century, which were perceived by Bender and artistically transformed in the post-war periodist poetry. Existential problems that have to be solved by his heroes are a reflection of those global and individual tragedies and disasters that have had a huge impact on the development of human thought and self-awareness and experiences of their being in the world.

Traces the parallels between the poetics of exile forced by Bender and the prose writer's appeals to existential issues in post-war modernist writing. Vitaliy Bender considers the life of the emigrant as a continuous existential initiation in a new space, therefore one can assert the author's organic philosophical affiliation and his work to the general artistic and philosophical discourse of the Ukrainian writer's diaspora of the post-war age.

Key words: existentialism, poetics, motive, being, initiation, exile, alienation, emigration 